\title{
THE AUTOBIOGRAPHY OF NICHOLAS RAY Susan Ray
}

After a screening of Parallax View at the 1974 San Sebastian Film Festival I recall Alan Pakula, the film's director, shook Nick's hand, gave a bow of the head, and uttered the word "Maitre." It was a courtly gesture that left Nick both touched and flustered. As witness to such a rich moment I posed to myself some questions: What is a master and what makes Nick one? And what does this mastery of his mean to me?

Mastery to my early mind meant a kind of perfection, a control over craft and circumstance. It was a quality in a work or a life, it seemed to me, that one could not miss or mistake for any other, that would show itself in an orderliness or a harmony and a powerful calm. I found Nick's films unmistakable, but not for their order or calm. As for Nick himself, he was at that time despairing in alcoholic disease and waging battle to support the completion of We Can't Go Home Again, not to mention his basic survival. Both his life and work were out of control. I wondered if Mr. Pakula had been too kind or perhaps he had made an error in judgment. Still I held my questions in mind and have continued to do so for years, particularly while working with the materials from which this book has been made.

In September 1969 I took a train west from Connecticut, where I grew up, to enroll at the University of Chicago. I wanted to go to Chicago to study because it was in the heartland, whatever that was, and because the school claimed to care less about teaching right answers than how to ask questions. I also had heard it had the highest student dropout and suicide rates in the country. 
I was a curious girl who wanted to know what made things what they were, but I had not learned much by knowing right answers. I could not find the key to my mind, while behind its locked doors stirred vague inklings and the fiercest hunger to contact the world and cut loose from whatever was binding. Pressure was building. I wanted experience, fast. Confused as I was I feared the dense thought forms at school might be just more fog in my way, so before I arrived I was planning to leave, though I had no idea where to go.

Except I did like the idea of a teacher-a private tutor, perhaps, or someone to whom I could apprentice. In what? I could not admit that the skill I wanted to learn was living, so for lack of a better idea I called it writing. And whom did I have in mind to instruct me? To tell you the truth, Norman Mailer. Norman Mailer knew how to write, he often cut loose, and the clincher was he could act. I had not met Norman Mailer, had no plan to meet him, so I kept this idea to myself and signed up for a year at school.

Two months later in a gust of cold wind and the clear morning light I met Nick. We were introduced by Bill Kunstler, attorney for the Chicago 7, at a crosswalk near the Federal Building where we were all headed for the trial. I had seen Nick before in the courtroom press box or stalking the hallways, always with young people around him. He was hard to miss, for his auric field spread out to the walls and crackled with high-voltage charge. Tall and white-maned, the coolest of cats, he came and went as he pleased. Nick, Kunstler told me, was making a movie about the trial and I, he told Nick, was a student at the trial to do research. It was the month of my eighteenth birthday, three months after Nick's fifty-eighth.

"Is that what you do, make movies?" I asked him.

He nodded it was, and held out a cigarette-

"What movies?"-which I took.

He listed some titles, all unknown to me. His movies, I figured, were not very good.

But the man himself looked noble - that was the word I used to myself_-like a king who had lost his kingdom or Odysseus after the wars. I was studying myth so archetypes ran loose in my mind, but I did not presume any heroes would have time for me nor did I expect to meet up with this one again. On the other hand, in his gaze, an arctic blue seascape, there was so much room for movement I could have turned cartwheels right down the icy sidewalk I was so grateful. Instead I skipped once to sync my right step with his and on the next beat he skipped back. 
The trial went on for another two months and I kept cutting classes to get to the courtroom to watch it. It was the best show in town from several points-of-view, but most compelling to me was the play of three generations of Jews-judge, defense lawyers, and several defendants - turned one against another, each crying betrayal. Although the cause of conflict was clear and in more than one sense familiar to me, the conflict's outcome was not. It was not a casual matter to me to know which generation if any would win.

As the time came for attorneys to present closing arguments, the country's first-string reporters flew into town and I had to surrender my seat in the pressbox. That I would not witness the trial's resolution was a defeat in itself and it left something dangerously dangling in me. I went back to campus a stranger to student life and far behind in my classes, having never really begun them. I did not know what to do with myself.

While the jury was out a reporter I barely knew from the trial sent a cab to my dorm one morning to take me to Nick's house on Orchard Street, I still don't know why. But I got in the car and, as a good story goes, drove over to a new world.

Nick's place was all movement, a dense buzz of people with jobs to do. The living room was the work room with couch, projector, and amassed on the floor, orderly piles of batteries, recorders, cases, lamps, gels, spools, reels, and tins around which feet stepped and heads met to talk. Eyeing the scene with the majesty of a sunning reptile, a black camera poised on a tripod. And groggy but perfectly easy in eyepatch and leopard-spotted bikini, there was Nick. He prowled through the room, mumbling directions through a French cigarette hanging out the side of his mouth. I could not hear the words, but his voice rumbled up from some startling depth like the purr from the belly of a great cat.

Yes it was a wonderful jungle, teeming with exotic life. How would I get myself into this life? Well here one just dove. So I gathered some dirty dishes and carted them off to the kitchen. Soon Nick came in to chat while I washed. He said he would be taking a crew out that afternoon. Would I stay to answer the phones? Yes I would be happy to do that.

When he got back that evening he stacked some court transcript before me and asked me to edit it into a film script. I told him I had not seen a film script before. He told me I would figure it out but offered a hint, like a trick to opening the cap on a jar: I should look for events that advanced the action. Some hours later, as I headed 
out for a cab, Nick came to the door, folded some cash in my hand, and said, "Here's a week's pay and cab fare. Be back tomorrow at ten."

Once I went to a carnival later on its last night in town. The carnival people had to pack up the works between midnight and four in the morning. I had fallen in love with the ferris wheel, an enormous elegant structure shaped like an infinity sign and built from no more than truck tires, colored lights, ropes, and crude metal bars. All those parts went to bed in a small pickup truck. I watched the wheel's dismantling piece by piece. Under lights strung on trees and telephone poles it looked to be the most gorgeous, perfectly choreographed ballet in the world. Each worker knew just where he had to be when, and how every piece had to fit in the truck. Each had the strength of a weight lifter, the dexterity of a juggler, the balance of a high-wire dancer, and enough true grace that when one man slipped off a bar at a height of some twenty feet, before I could gasp, before he hit ground, there were two men below to catch him. A detail about carnival folk to which I gave little thought at the time: they all carried switchblades in their back pockets.

The people on Nick's film crew were just like that, high-tech carnies except for the knives. They all had the same goal, they worked for the show, so they helped one another, they helped me. Every day was different. Every day demanded a range of skills I had not thought of using before and my skills were useful to others. The day did not stop at darkness but took on more life under lights. There was no fixed schedule, activities just gathered focus and happened. The crew was together from morning until after midnight. We shared meals. The work and our lives became one. We were a family. It seemed to me there were no limits to what such a family could do.

Of course, heading this family and stretching the vistas before me was Nick. If I learned in time how he used Frank Lloyd Wright's inclination for horizontals to expand the frames of his pictures, I experienced that expansion in Nick the first time I met him. In him it was a cellular thing and profoundly hopeful. In such generous space whoever, whatever, however I was at a given moment was fine. In such generous space I felt I could dissolve the knot of myself, let my nature relax, and finally join up with the world.

At the end of the day when his workers, most of them half his age, could barely keep themselves upright, Nick was still going strong and seemed able to do almost every job at least as well if not better than those he had hired to do them. (Of course his techniques were of a peculiar order. To this day I am not convinced he ever learned the 
mechanics of a camera, but he would kick the damn thing, put his half-blind good eye to the lens, and always get his shot.) He moved from building the set, to writing the script, to shooting a demonstration, to negotiating with lawyers, to discussing the latest government scam, to mending a broken projector, to musing on what would be nice for dinner, to screening dailies, to soothing a ruffled assistant, to viewing the new play in town, and then back to work on the script, all in the span of a day and with full attention and care. But stamina, skill, and concentration were minimal requisites for a director, or so I assumed at the time.

Other ways of Nick's were odd to find in someone accustomed to Hollywood gloss. His place looked like a student's apartment: dissheveled mattress on the floor, bare lightbulbs, an array of cups, ashtrays, magazines, books, and papers spread among film equipment. Nick had chosen a crew of young people, myself among them, many of whom were unknown and unproven, and he spoke to us with respect, curiosity about what he might learn, and the expectation that we would find a way to do whatever he might have to ask.

After only one day at Orchard Street the decision was easy: at the end of the term I would quit school and join the adventure, whatever it was. Whatever it was, it was what I had been waiting for.

Nick was not one for cosmetic disguise to his person, history, or habits so I held no illusions, I knew early on that he was monstrous. One day he aimed an explosive and public display of bad temper at a devoted young man who turned out to be his son Tim. (The outburst was not caused by any lack of affection from either but by Tim in some way having shown disrespect for the celluloid strip, or so Nick insisted.) Nick never opened his mail, seemed not to have to pay bills; he just pitched the unopened letters my way to get rid of. He drank wine for breakfast, "a source of vitamin C" he told me. And then there were the medicaments, a briefcase full that went with him everywhere: needles, ampules of methedrine and B-complex, mysterious pills, bags of grass, blocks of hash, and fresh patches for the right eye whose vision he had lost to a bloodclot. When the moment was right, no matter where he was or with whom, he would drop his trousers to shoot himself in the hip with a mixture extracted from the little glass bottles. He needed this to keep himself going for his doctors had given him only one year to live-he told me this every year of the almost ten that I knew him. His body was built to live to 100 but he had worn it out. He further explained: "The attrition has been tremendous." 
I did not know this word attrition. I looked it up: "attrition: 1. sorrow for one's own sins that arises from a motive considered lower than that of the love of God; 2. . . the condition of being worn down or ground down by friction." 1

That sounded romantic, but to my observation there was nothing at all ground down about Nick. No matter what he put in his system his energy did not quit.

But the money did, overnight. With a shift in political winds the investors in the Chicago film withdrew. Overnight the carnival packed up and left town and the Orchard Street place closed down.

The moment was telling: a life in moving pictures could be cruel, there were knives, and attrition was the word after all. Film families were just as unstable as others and on the other side of bright lights lay shadows equally dark. It was my first intimation that I could not live beyond my own means, of whatever kind. If I had had an idea that in the effusion of his creative juices Nick could slide me past the stoppage of my own, I was in for some jolts. But there were many facets to this understanding that would take me a while to grasp.

As for Nick he kept splashing the paint but his palette got darker. I knew nothing yet of Nick's history and not much about the weight of dismay on the heart when an old well-known ghost starts clanking its chains and slamming doors in one's face. Still, not much was enough so I knew whether he said so or not to Nick the film's shutdown was such a ghost. A great will arose in me to lay the ghost down to its final rest, for myself as much as for Nick. To do so became my purpose. Since purpose was new to my life and most gratefully welcome I did not examine its rightness or roots.

Nick continued to gather numbers of people around him but now only a few stayed to work. Of course I stayed on, I had no thought of doing anything else. Why did I stay?

He had a tender touch for small creatures. He laughed at my jokes. We were dropouts from the same school. He knew how to have adventures. As the Zen master's wife once said about her husband, "Compared to him all the others are fools." If I had once thought he could help solve my problems I now thought we had the same problems, but his were bigger and better, so I would help him with his and mine would get solved in the bargain. He was always interesting to me. I felt at home with him.

1. Webster's Third New International Dictionary (Massachusetts: G. \& C. Merriam Company, 1966), p. 142. 
And why did he want me with him? I was new. He needed someone to pick up after him. We had the same problems. I told him his jokes were lousy. I was so lost I had to be looking and above all he honored the search. I caught his drift. He liked my twists. He felt at home with me. I would not go away.

Soon we dropped all politeness between us for a mode of exchange better suited to both our natures. It was harmony based on dissonance or as one observer described it: "You like each other, you understand each other, but you can't speak a civil word to each other." Others took our back-and-forth for a new form of burlesque entertainment. I can see now it must have been droll how Nick coolly poked his way through my sore spots to turn me into a foaming savage, although at the time I did not always catch the punch line.

In retrospect I believe Nick got jealous sometimes, as people can do when they feel themselves aging and faced with someone looking all promise without final loss or failure. I got jealous too, of his commitment, power, and achievement, so I did not see what he had to be irked about, but whatever it was it could make him mean. "Don't enter into battle with inferior weapons," he would taunt any challenge from me, no matter how worthy. I knew my weapons would not hold up, he did not have to tell me, and nothing made me madder than that. But then no one had ever let me cut loose with my rage before and cutting loose in some form was what I was after.

Finally I went with a friend to see one of Nick's movies. When his name flashed onscreen I jabbed my friend in the ribs, but after the first fifteen minutes of story I was slipping down the back of my chair toward the exit. I told Nick frankly I had not been impressed. "Which film did you see?" he wanted to know. "Born To Be Bad." "It sure was," he giggled.

In April 1970 I joined Nick in New York where he had gone to find backing for the Chicago film. By day we worked in the cutting room preparing presentations or looked at paintings and visited his old friends. At night we went to dinner and theatre. Prospects for the film were poor. Nick was low on cash and wanted to get back to Europe, to the island of Sylt in the North Sea where he had a house and was planning to build a sound stage from driftwood. There I could write, he told me, and work as his apprentice on the films he would shoot on the sound stage. No plan ever had sounded so perfect. I could taste the salt air.

First we planned to fly back to Chicago, but the airlines were striking so we took coach seats on the train. Traveling cross-country with 
Nick I felt like a pioneer woman, the frontier stretched before me so vast and near. By the time we arrived at Union Station, sooty and having spent the night at gin rummy, I had learned not to play to an inside straight and it seemed the best thing that we should go on together.

By summer we were settled in New York. Nick deposited me at the apartment of his old friend Alan Lomax. ${ }^{2}$ Sometimes he stayed with me at Alan's and sometimes he stayed with Connie Bessie, ${ }^{3}$ another old friend, depending on who at the time was less irksome.

Back in New York after ten years away Nick picked up the threads of the life he had lived decades before during the Depression and Second World War. He revived old friendships with Alan and Connie and with Jean Evans, John Houseman, Gadge Kazan, Les Farber, ${ }^{4}$ Max Gordon, ${ }^{5}$ Will Lee, ${ }^{6}$ and Perry Bruskin. ${ }^{7}$ With them he was a rough kid, a scapegrace, indulged, prodigious, awkward; but he seemed to me purer that way and gladdened to find his old friends and be seen once again through their eyes. I guessed that the Depression years had been good years for him and he said that was true. Without money people had to help each other and work together, so invention had flowed and values had stayed simple and clear.

Mostly Nick did not like his generation. He thought them betrayers whose acts of betrayal were in his words "like asking your kid to jump into your arms and then pulling your arms away." He was more at ease with my generation, while I was not, and he seemed to know more about them than I did.

That summer he hung out on the streets and like any cat he did his stalking at night. From an office he had been loaned in the Palace Theatre-where Lauren Bacall, widow of one of the men he had most loved, was then starring-he would look out at Times Square and

2. Ethnologist and Nick's colleague with whom he collected folksongs for the Library of Congress and produced the CBS radio show of the early forties, "Back Where I Come From."

3. Née Connie Ernst, whom Nick had met while working at the Office of War Information in the forties, and to whom he was briefly engaged.

4. Psychiatrist and author of The Ways of the Will, to which Nick refers in his classes.

5. Owner of the Village Vanguard, a center for the New York jazz scene for decades. Max's was the first face Nick saw that he knew when he first came back to town.

6. Who worked with Nick in the Theatre of Action.

7. Also from the Theatre of Action. 
wait for the limos to leave and the marquee to go dark. Then he would emerge with the night shades-pimps in zippered zoot suits, whores in pastel boas - as they barreled down Broadway in long white $\mathrm{T}$ birds or strutted the sidewalks, radios at full blast. Nick roamed among them monitoring their moods and comings and goings, trading insults with winos, drinking at local bars, playing cribbage, pool, poker, and endless rounds of bingo at Fascination on 48th Street. (The doors to Fascination were lit like a pinball machine. When I went through them the caller would greet me over his mike, "You looking for Wiley Post?"8 and point the way to Nick's station. Known or unknown, Nick was never unnoticed.)

The whole Broadway scene absorbed him-its dance, colors, language, con men, and crooks, and the ferociousness of what he saw as "the fight for the watering hole." He began to write a screenplay, New York After Midnight, about a man called Eyepatch who returns to New York and Broadway to encounter loose ends from his past among present more savage despairs.

As Nick came and went I wondered why the man would not take for himself those most basic instinctual comforts any animal needs for refreshment: he would not sleep, he would not come in from the cold or the heat or whatever the element of the season, and if someone did not spread a meal before him he'd get by on white wine, tobacco, beer, gin, Mars bars, and those high-octane injections. This behavior I called perverse. It went against nature and enforced my impression that Nick's house was haunted and he was the ghost. He seemed to believe that if he did surrender to sleep, sleep would seduce him and keep him from ever finding his way back to waking. So he more or less ceaselessly roamed, dragging behind him his noiseless invisible chains. Just as a specter floats through walls so Nick seemed to move from night into day into night, from outside to inside, between sleep and waking, between death and life, defying, ignoring, dissolving lines drawn between oppositions.

I did not go on these jaunts even when asked (I needed sleep, I needed to find a job) but waited until he had worn out his companions and even his body refused to go further, when finally at dawn he would come home to refuel. After a meal he would collapse into sleep until noon, when he would want to be roused for a meeting.

His waking was a dreadful event and not just for him. It would

8. A craggy character played by John Wayne wearing an eyepatch. 
begin with deep moans, a blind reach for tobacco which knocked bedside things to the floor, the strike of a lighter, a lengthy inhale, then hacking coughs and more moans. Then shielding his eyes against light he would mumble "Feet." Nick's feet, I knew because he had warned me, would not support him through the day unless they were rubbed. Once this was done he might sit upright.

And so he would, on the side of the bed leaning elbows on knees, head hanging, with a cigarette in his mouth. Like a stone he would sit for a very long time in silence unbroken except for the sound of his ashes falling to ground. As I had not yet begun to explore silence on my own I found his dense weighty kind hard to take, but I tried to just let it be. Then my first approach was always gentle, cajoling: "What's bothering you?" I'd ask. The silence sank in response. "It couldn't be that bad, could it?" Well it could, it was far too bad to discuss. "Say something, would you?" He'd just draw in smoke, pull the cigarette from his lips- "Nicholas, you're going to be late" —and exhale. "Nick!"

Finally he would turn my way and we'd enter a new and more verbal stage of negotiation. I could usually catch "attrition," "betrayal," or "sonofabitch" in the mumbled part of a sentence he'd offer. I would sit by his side and wait for the rest, but I had no patience for vacuums so I filled up the air with pep talk: this would be a really good day, he had so much to offer, so many loved him, his fortunes were about to improve - Cutting into my sentence at last he'd finish his (the first part of which I'd by then forgotten) and slowly rise to his feet. I describe this routine in such detail because in the almost ten years I woke up with Nick he did nothing else more predictably. ${ }^{9}$

One morning that summer looking up from his feet Nick told me while making 55 Days to Peking he'd had a nightmare and that when he woke up from the nightmare he knew he would not complete another film in this lifetime.

Seasons changed and Nick spread himself like a vast organism over the town: he was at Warhol's Factory and the Electric Circus, Village bars and the Vanguard, Max's Kansas City, off-Broadway theatre, Times Square, East Side embassies and salons, and the hidden lofts of eccentrics dealing in mind expansion. He wanted to know what

9. Apparently such behavior is not uncommon. See Françoise Gilot's Life With Picasso (New York: Bantam Doubleday Dell Publishing Group, Inc., pp. 154-156. 
was going on but his role was not the observer's; whatever the scene he had to take part and his part could not be small. He made himself at home everywhere (except in some old-blooded circles where he became a rough kid again or assumed British tones which were met with mild disdain). Everywhere there were those who were ready to join him and stay on for life. They gave him their talismans, cash, and time, but when the tide turned many found themselves beached while Nick passed by on a wave. No matter how short-lived the contact had been the ones left behind seemed to grieve it.

Nick wanted a chance for his film-if not the Chicago film then any film that could stir him - and a chance for a film always means money. There were many young and old writers eager to have Nick Ray help develop their screenplays, so on the condition that he would direct he helped them. They gave him meals and get-around money until the projects aborted.

In winter 1970 Nick met Bob Glaudini, Terry Ork, and Sam Shepard, all at work on Sam's Cowboy Mouth. Nick sat in and advised at rehearsals. He also sowed seeds for a book about leftist theatre ${ }^{10}$ and had his hand in a half-dozen other creative ventures at any one time. (He was always a wellspring of juicy ideas, the fullest, most generous I've encountered to date without exception.)

Meanwhile I set about seeing his pictures. Where I grew up film was still considered a bastard art to enjoy but not recognize. I loved to go to the movies but was no cinephile. Apart from what I'd absorbed in a year with Nick I knew nothing of cinema technique or history. I had no trust in public opinion so all the good things I'd heard about Nick Ray's films meant less than nothing to me. Still I wanted to know what the films would tell me about the man who had made them.

Nick's movies were far too disturbing to be entertaining. They offered no peaceful place. They made me work and I found myself not always eager to see them. Sitting through Johnny Guitar from beginning to end I took barely a breath, the tension was relentless. Seeing Hot Blood I thanked my stars I'd met Nick only after his engine had run down a bit. Watching Bigger Than Life I recalled having seen it years before on TV one lonely weekend, and having been sick at the sight of madness so close to home yet unable to turn it off as it ran on the screen and later in my mind. Sharing with Nick my memory of that time I told him, "This is your story before you lived it." But

10. Jay Williams (Stage Left, New York: Scribner, 1974). 
each film was his story, nakedly so, and each story was different, so I had to marvel at the scope of his life and his willingness to let others see it (I did not at the time think it courage).

I did not want to like Rebel Without a Cause-everyone liked Rebel, almost a contradiction in terms - but how had Nick known about the claustrophobia of suburban life and what it was like for someone like me growing up? And what was all the fuss about Dean when Dean was so clearly - to me anyway-aping Nick?

How did Nick know about the acid women can hold and sometimes explode with, as does Emma in Johnny Guitar? Or about how the air seems to knit itself between two people in love, like Charisse and Taylor in Party Girl or Mitchum and Hayward in Lusty Men? How had he learned his respect for simple everyday people, for their troubles, dreams, heart, and reflections, while living his complex uncommon life? Whatever it was I expected Nick pushed beyond expectation, tilted, took up or down half a pitch, not for the sake of risk or contortion or in defiance of truth but because expectation can be a thick skin and Nick's truth was raw and skinless. If Bigger Than Life was his story, Savage Innocents was his soul-the title said it all.

One early morning we watched They Live By Night on TV. Bowie looked to me like pictures I'd seen of Nick when he was young and I said so. Nick nodded and rambled on for a while about the first shot ever made from a helicopter, but by the end of the film he was weeping.

That Nick knew more than I had ever imagined did not surprise me, but until seeing his films I had not known how much he felt. For me then, so young and unable to support my own nature, it was simply too much to bear. But the films, I had to admit, were not so bad after all.

We both were at loose although opposite ends. He at least knew his calling and had a wealth of people to see things to do on his nightly jaunts, while I was too unsure of myself to look for my own friends and occupations and was not about to trail in his shadow. One day I drew a faceless self-portrait. Nick wrote on the page: "She is already who she wants to become." Who was that? I longed for but did not know her so it was a deep and warm comfort to have her so coaxed to light.

I could not, however, count on comfort from Nick.

I read Norman Mailer's essay "The Prisoner of Sex" in Harper's ${ }^{11}$

11. Norman Mailer, "The Prisoner of Sex." Harper, March 1971, vol. 242, pp. 41-46. 
and passed the magazine meaningfully to Nick. Here was a teacher, I let him know, and maybe if Nick ran into Norman he'd tell him about me? Next morning Nick gave back the magazine, but the essay in question had vanished beneath the collage of cutouts, tape, and commentary he had built over it in the night. When it came to finding Norman I was on my own.

Another morning some time before dawn Nick shook me from sleep to say he'd brought some people for me to meet. I came out from the bedroom sour as a lemon, but when I set eyes on the couple I was not sure I had waked up yet. Before me stood a red-haired Merlin and the goddess Kali in hotpants. I took the woman off to a corner, for I wanted to know why at four in the morning she had come to my house. She put up with my questions and then caught me straight in the eyes: "Don't you see, he wants you to have a friend." Nick had found this woman at a Grateful Dead concert in a full crowd on closing night at the Filmore. (She and I are still close and, as it turns out, are related by blood through our mothers.)

At the same show Nick bumped into Dennis Hopper, who before long offered to fly him down to his ranch in Taos, New Mexico. I was to settle things at my job and then follow.

Nick was unemployed, about to turn sixty, and methamphetamine had just been made illegal. It was a good time for him to get out of town. In Taos Dennis provided shelter, food, drink, entertainment, new faces, wide vistas, guns, horses: a deluxe outlaw's den where Nick could rage freely. When he met me at the airport I could see right away that he'd gotten wilder, gone over an edge he'd held back from before. He was acting a caricature of himself, a limping oneeyed satyr, and for the first time he seemed to think himself old.

He had grown a beard and a surplus of paranoia and had taken to wearing a gun in a holster. I did not like the beard and thought the holster was asking for it given the state of his judgment and eyesight. So he shaved the beard and shot a rattlesnake in a stone wall. There are those who witnessed the shooting and Nick pulling a snakeskin (we never did find the body) from the rocks who claimed the skin was a plant, but either way he had made his point.

When he wasn't at target practice or out god knows where with the boys he tinkered with his script Mister Mister, a western about kids who seize control of the town from their parents. He also sat in while Dennis cut The Last Movie, a film he liked very much. A salesman came out to the ranch to demonstrate his new products, videocassettes and a machine on which they could be played in the home, 
and Nick observed: "In ten years people will have stopped going out to the movies."

Nick was withdrawing from speed, if from nothing else, and at night he suffered terribly, requiring non-stop vigilant care to his feet. One night between moans he asked me to marry him. Since by then I knew I would be with him at least until one of us died I told him we could consider it done. Nick gave me his ring, I gave him a pearl, he went back to moaning, I went back to rubbing his feet. Next day he was up and out and kicking up dust as before while I caught up on my sleep.

The visit to Taos offered daily adventures, great beauty and space-I had not seen tumbleweed or the Rio Grande before-but Nick was knocking around among too many rocky unknowns. He was caught in a change and I had to wonder if he would ever get loose.

Nick's history has been well told already; ${ }^{12}$ it is enough to say here that in early 1971 he accepted a job to begin teaching film that fall at Harpur College, State University of New York at Binghamton. Nick moved there in late summer. I planned to work four days a week at my job in New York and join Nick upstate for long weekends.

Binghamton was a valley town with dense and damp air that could weigh on one's mind, even if nothing else did. Still Nick went to work perky and full of plans. He bought himself a white truck and red jacket, commandeered some equipment, applied for a government grant, and outlined the structure for his class. The students would rotate jobs-from acting to camera, lights, script, props, and wardrobe-to study the problems of craft, technique, and how to work as a group. They would learn movie making by making a movie. But what was the movie about?

I suggested as subject Nick's ghost, the "premonition" of a decade before that Nick would not finish another film. By addressing the ghost Nick would chase it away, or so I believed and argued. Nick began writing a script called The Gun Under My Pillow. One night as he wrote an ambulance drove by our rooms to the infirmary nearby. A body-we never found out whose or its condition-was wheeled out of the truck on a stretcher. Nick threw out his first few pages and began again with the approach of a siren and red flashing lights.

12. See the biography by Bernard Eisenschitz, Roman Americain: Les Vies de Nicholas Ray (Paris: Christian Bourgois Eidteur 1990), published in English as Nicholas Ray: An American Life, Trans. Tom Milne (Wincester, Mass.: Faber and Faber, 1993). 
For their first assignment Nick sent his class scurrying off to find film, props, and equipment to start shooting that night in the infirmary driveway. As was his way Nick dove right in and took everyone with him. So as not to disrupt other classes and with an outlaw's preference for darkness he called his class for nightfall. Night after night they shot until dawn fueled on wine and illicit white powders. Secrets were shared, loves and hates erupted to be soothed or abandoned, and everyone got very well acquainted.

Nick observed that an era of social action and conscience was over, young people were pulling back into themselves to "do their own thing." The students brought him their stories and the stories were always about what Nick called "the search for self-image." Soon the stories began overlapping and, as told to a movie director "long discontent with life in the capitol of the dream merchants" but concerned with the nature of image and self, they became the fabric of the film called We Can't Go Home Again.

Although he was never not introspective Nick too became more withdrawn, like a Chinese sage who after achieving enough in the world takes up the life of a hermit surrendered to nature and the paradox of his own spirit. Only in Nick's case, again, the transition was not smooth.

I could only watch. Somehow I had slipped from my role as apprentice, king's jester, and sidekick, for which I had felt very well suited, to that of gofer, shrew, and occasional solace, for which I held no respect at all. I still had no focus; this was my greatest problem. There were excuses: Nick was so big and close all else was blocked from the view of my lens; and the great man's wife no matter who she may be is rarely seen in full light except as ornament, obstruction, or big mistake. Still I was stuck, and railed with envy as Nick nursed and prodded his students - who were, after all, my own age-into a film crew and family. He gave them his time, fretted for who they were in themselves, drew out their poisons and poems, and expected I would work things out on my own while tending his papers, ideas, budget, and feet. Which I did, but not always sweetly. At least I held onto my job in the City and kept my visits short.

And the cameras kept rolling. In the two years of his contract at Harpur Nick shot most of a feature film. He also antagonized most of his colleagues and the school's entire administration. This was no surprise: they were inclined to make or maintain rules and Nick was not. "In the land of the blind the one-eyed man is king," he explained. He was sure they were sabotaging his project-I can only guess what they thought he was doing-and his suspicions may not have been 
so far-fetched. But then I never saw him get along nicely with any authority, not without muttering under his breath minimum.

In 1973 we took an early incomplete version of We Can't Go Home Again to the Cannes Festival, where it received a standing ovation. A number of people offered Nick money to complete the work, but the amounts were not enough or the backers wanted too much control. After a brief stay in Amsterdam Nick took the film back to the West Coast for lab refinements, but much of the workprint got lost or damaged in transit and then, according to Nick, the people who were supposed to be helping kept screwing up. When it came to this film things went wrong with uncanny consistency. More than once Nick called in the deep of the night to announce, "I'm throwing the whole goddam thing in the ocean."

For the next two years while I stayed in New York Nick flew back and forth between east and west coasts carting boxes of work print. His stated purpose was to scare up backers so he could finish the film or find some other film to work on. But nothing was working and again I had to wonder. Several editors lamented to me that they would cut a sequence just as Nick had directed and the sequence would look fine, but next day they would find it had been pulled apart in the night. Was this Penelope at the loom? Francis Coppola offered Nick an editing room but then took it back because Nick and his crew kept tripping the Zoetrope burglary alarms on their nights out to the wild side. Nick wore out all his hosts. Reports of his outrages came to me from all over as he cut a wide trail through new friends and old. Those who had scolded me for my bad tempers with him began to call in spent voices to say: "He really is monstrous."

I could have taken some satisfaction in having said so all along or delighted at the range of his exploits - so original, so funny, so perfectly played-but Nick was sinking fast. He no longer could drink without becoming a falling-down drunk. Each time he came east he looked more wracked and fragile. He kept trying to stop the drugs and booze but could not. I would get him to doctors, feed him, and put him to bed but he would not let himself rest. His despair grew denser and denser, like a black hole sucking everything in.

Then just as it seemed he was down for the count he was up again and covering ground like a fire. He went back to work on We Can't Go Home Again and made notes for an autobiography. He filmed a country music festival in Turlingua, Texas, spoke at schools, and flew to Spain to head the jury at the Film Festival at San Sebastian-where his translator would not translate his apparently demented speech and Pakula called him master. 
Around this time he also wrote me this letter:

[San Francisco, 1973]

FROM: Nicholas Ray

TO: Ms. Schwartz

217 East 12th Street

Manhattan

SUBJECT: Biography of Nicholas Ray

It has seemed to me that ever since the subject of my biography or "autobiography" has become a factor in some of our discussions that you would be the only person of my acquaintance who would be capable, talented and humorous enough to write such a work, unworthy as it may be... . But if you are to do it, it should be soon. Externally I am still able to laugh at me and conciliate myself with rage; internally, only you, and on rare occasions, Tim, can make my belly roll, my tears appear and the nakedness of my thoughts become expressable, whether or not they would be comprehensible... . Who else knows more about my absurdities than you? Perhaps all people I've encountered have seen the fragments - no one else the entirety....

Right away and in a cooperative spirit I contrived an outline and began to gather some notes. But I had no idea how a life wove itself nor interest in telling a factual history, even if it were Nick's. The job was too big for me; I had trouble enough with the man himself. So I filed his letter away with my notes and watched Nick turn orange with yet one more frustration. The task had been set, however, and if I did not understand it I also could not forget it.

In the spring of 1976 in New York Nick began work on a film called Murphy's Law about a New York City hooker and storefront lawyer, both down on their luck and lonesome. The project's producer found Nick a fine office and studio space and asked me to join the production staff. The budget once raised would allow for professional actors, equipment, and salaries all around. The word was out about Nick Ray's new film. Rip Torn and, of special interest to me, Norman Mailer ${ }^{13}$ were going to take part. Only the major monies were still

13. My long awaited meeting with Norman took place at a midsummer costume party. We had been introduced already at the film office, where he had shaken my hand and moved on. Upon eyeing me in my costume, however (I came as a fool and he wore the dark velvet robes of a medieval scholar), he told me I had surprised him and invited me to a "dialogue." I could barely speak for spasms of shyness, so said something rude and skittered away to find Nick, who came as a white knight. 
outstanding. With the tax shelter laws then in effect we were sure we would have what we needed.

With some change in his pocket Nick easily found all the herbs, liquids, and powders he claimed he wanted to quit and he went for them all; but he stayed on the job rewriting the script in three days, scouting locations, talking with actors, abounding with visions and plans.

In the course of things the blonde who was to play the lead confided to Nick that she only looked good in blue. Blue, he told me, could cause trouble on film as even a tiny Delft teacup would tend to bleed through the frame. He nursed this dilemma until at lunch with the costume designer he awoke from a doze over his soup and announced, "We'll shoot the whole thing in blue and call it City Blues." A simple solution, but to find it he had had to embrace a breadth of given conditions, from the sorrowful moan of the City that summer to the ache in the story's hero to his star's demands for her wardrobe. It struck me then that the man's thoughts did not follow in lines but exploded in spheres, whole worlds at a time, and that his technique of multiple image was not cinematic invention but really the way that he saw things and some form of the way things were meant to be seen.

I also observed that beneath Nick's acceptance of so many givens and his willingness to allow their essential connections to bubble up and find their own unity, there had to be faith. This man who manipulated so boldly, told preposterous lies, and suffered and suffered had the deepest respect for earthy, raw, foolish life as it was.

The first day of shooting on City Blues was postponed and postponed again. We still had no deal and then the tax shelter laws were repealed. Every night I told Nick, "I still think it will happen all right"; then asked him, "Do you?" The producer kept proffering promises but summer was nearly over and Nick shook his head: "There's a familiar stink in the air." We had no money nor home and were living off the kindness of strangers. Nick drank day and night. Victor Perkins, ${ }^{14}$ in town for a week, nursed Nick through the first draft of a script for a horror film. But the horror was not just on paper and finally I had to leave.

A week later, in September 1976, after falling down a flight of stairs, Nick checked into the detox unit at Roosevelt Hospital.

14. British film critic. 
I went there to see him. A social worker pulled me aside. She said, "You know he's very sick."

I told her I knew that. I told her he had been very unhappy for a very long time and that was why he drank and took drugs.

She said, "If he doesn't quit the drugs and booze now he'll either die or turn into a vegetable, guaranteed."

The brightness of Nick's gifts, like the proverbial lotus flower, grew roots in the mud of his rage and despair; it could not have shone had he not met eyes open with darkness. But a crucial balance in Nick's growth had gone askew; what had been rich soil was now quicksand. That Nick made the choice not to go under, to quit drugs and booze and begin a recovery program, was as far as I know the most difficult act of his life. He pulled up short in his tracks, turned one-eighty degrees, and locked eyes with the ghost that had chased him for sixtyfive years. He was scared, hurting, and in need of help and he said so out loud and to others. Such honesty had come to look foolish to me, too naked and risky, but when I saw it in Nick it was revelation, heroic, a quality for me to strive for. And I knew it had something important to do with the cutting loose (cutting through) I had always believed could make life fresh and free.

In November Nick was released from treatment and back to the world. We found a new home, finally a place big enough for us both. We looked for jobs and joined other couples for bridge and quiet evenings at home. Nick worked to get well with a trust that was so conscientious it could not help but rub off on me. I began to learn ways of calming my mind, and this helped the days pass more smoothly. Nick said, "I wish I'd learned that stuff at your age."

Nick went every day to Alcoholics Anonymous meetings. Sometimes I went with him. He liked meetings to which the hard cases would go, maybe because he was a hard case himself or because the hard cases were women and men who had lost their lives and found them again, so they knew a thing about value. Also they had good stories to tell and no time at all for jive. The truth blew through those meetings like a high mountain wind, sharp, clear, and chill, and we both felt enlivened by it.

Nick knew he had been given a rare second chance and his gratitude for it made him gentle and patient in ways he had not been before. A "vulnerability that one could not but be moved by ... even frightened," which he had described in James Dean, was Nick's vulnerability too.

That winter, supported by Elia Kazan and John Houseman who 
three decades before had started him in the movies, Nick began teaching at New York University and the Lee Strasberg Institute.

I believe Nick loved teaching, especially at this time. Teaching provided a laboratory in which he could research his craft and fellow humans. Teaching helped him to clarify his thinking and draw some conclusions. Teaching allowed him to guide and nurture young people as he himself had been guided and nurtured and had missed being guided and nurtured. Nick wholly gave himself to his students as mostly they gave themselves to him. I believe he felt a new peace at this time. This time had the tenderness of a seedling just before the first frost.

One early morning in November 1977 I had a dream. This was the dream: Nick was packing his bags. Talking over his shoulder he told me, "I'm leaving now, you don't need me anymore." I woke up as my fist hit Nick's face. Pouring hot tears, I saw he was already awake, watching TV and nursing a bag of chocolates. The blow did not seem to startle him much. He just gathered me up while I sobbed.

Two weeks after that Nick checked into hospital for tests. The $\mathrm{X}$-rays and scans showed a tumor on his right lung.

No young woman joins her life to that of a man forty years older without considering death. I had thought about death a lot in my time-my parents' deaths, Nick's death, death by Nazis, death by atomic bomb. Dying as far as I knew meant only pain, terror, decay, and the deprivation of life for whomever was dying. Dying concerned me a lot-my own death did not-but I thought nothing worse than the limitless hard cement landscape of grief I would be left alone in by the death of someone I loved. I had never seen death close up and I knew I would have to before I could understand anything, but if given the choice I would let understanding wait.

If understanding would wait death would not. Surgery followed diagnosis by days and the scalpels cut nothing but hope. The cancer had grown around Nick's aorta and had probably entered his bloodstream. The doctors sewed him back up with his tumor intact. In their fondness for numbers they told me they gave him two years and those years would be hard.

Nick had met with so many close calls I had lost count of the total, I could not recall if this were the cat's eighth or ninth and last life. For a while I believed if we both willed it hard enough Nick would get well.

No one told me nor could I have imagined what terrible beauty is loosed when someone like Nick is dying. Our culture, of course, has 
no place for dying so we have no tradition of study about that fifty percent of existence. Why get a guidebook to a country one wants to avoid? Which just goes to show how ignorant wanting can be for Nick's dying was an adventure, and since dying would not be avoided a guide to its ways could only have helped. So much for spilt milk. Nick's dying opened new lands for everyone who came near him, as for Nick himself I have to assume, for his wonder and alertness to the shifts in his world became only more acute.

I dreaded watching his mane fall out and his body shrink down to bone, but he did lose his hair and his body shrank down and everything extra burned away with disease. What was left was essence of life which in Nick's face took on a look of such pure sweet sadness it was transfixing. In his pain and exhaustion he could digest only what was most simple, basic, direct, and true. To offer him anything less seemed cheap and a threat to his vitalness, and yet I was young, undisciplined, and still an unknown to myself. Whether he had planned to or not Nick once again had set a hard task. When for moments I could meet it - meet him - fully and clearly nothing else mattered, all was complete. Such moments became the goldmine of his legacy to me. The fact is the way Nick was dying brought me to my life.

For the first time I asked Nick my real questions, only one or two every couple of weeks for I felt inexplicably shy:

Q: When you're gambling and on a roll how do you know your numbers?

A: Sometimes I hear the music of the spheres and I just know what the next note will be. But then I get cocky.

Q: If you could give me just one piece of advice what would it be?

A: Don't care so much what others think about you.

Q: One more piece?

A: Examine your fear of violence.

Q: Why wouldn't you help me get started the way you did all the others?

To this last he kept silent.

One day he turned from the cop show on TV to observe with some pride in us both: "You've become an experienced woman."

Of course a man only changes so much in a lifetime and his pain was horrific, so Nick did much moaning and with his best ploys and invention kept a crowd scurrying after his needs. He took to wearing a heating pad under his shirt on his back while pacing the long length of our loft. As we had few electrical outlets and mostly relied on extension chords, a friend spent his visit from London following Nick to 
and fro, frantically sorting wires and unplugging and plugging before the heating pad cooled or the TV was yanked off its table.

While in hospital Nick insisted on smoking in rooms where oxygen was in use, so to avoid explosions the nurses trained me to care for him at home and begged me to keep him there unless his condition became very bad.

Tim Ray and a medley of friends came for visits. Tim taught Nick meditations to relax the pain and to rally his psyche's fighting forces against the cancer cells. All joined hands to keep the house going, cooking and shopping, taking Nick to his radiation appointments, rubbing his feet, copying his notes, bullying him into taking his pills - whatever he needed. From the great bed at the end of the loft through moans and groans Nick directed this comic and bustling scene that with no decision on anyone's part had turned into a celebration.

Then in early spring of 1979 and for the last time the carnival came back to town: Wim Wenders arrived at the door with film, crew, and equipment. Several people, including Nick, had ideas for Nick Ray's last film but Wim made the strongest bid for getting the show underway.

Tripping on lights and cables trying to get to Nick's bedside I was not convinced that making the movie was such a good plan. That was like wondering if the tornado should have struck. Still, debating the point in my mind raised some questions not unrelated to the themes of this book and Nick's life.

Nick thought the film should concern a man sick with cancer who wanted "to bring himself altogether" before he died. Since that was what Nick himself wanted to do and since he had chosen to give his remaining time to the movie and that time was scant, it made sense to combine his two intents into one. Beyond that we had no script or plotline.

With such skilled improvisers as Nick Ray and Wim Wenders one would think no script would be no problem. But problems arose right away, perhaps because the laws of creation allow only one visionary per vision or more likely because fear broke loose. Fear took us over-not violently as it can do but by spinning sticky invisible webs. I cannot say for sure what stirred up the fear but I had not felt it so strong around Nick's dying before. As is its way fear not only made us all desperate, it distorted perception and instinct, and the film soon ran off like a terrorized child all alone in the dark night.

Did Nick want to make Nick's Movie (Lightning Over Water)? He 
never said so, even when I asked him directly. He did not want to disappoint Wim and his backers, he did not like what he saw of the dailies - that much he did say. He was too weak to work as he would have wanted to work and he saw for the time that Wim Wenders was lost, both behind and before the camera.

For myself I knew Nick would not live much longer, the time left with him was dear, but I could not get close for director, crew, and equipment kept blocking the way. It seemed Nick would not have the chance to "bring things altogether"; in fact things were flying apart. I felt the rite of the most sacred time in a life had been raped while Nick's and my need for each other was dismissed as inconsequential. Who was to blame? Were I to point a finger it would be at fear.

There were not so many good reasons to want to keep shooting that film, yet I could not find the strength in me to try to stop it. I had to conclude that given the chance to film his own dying Nick could not pass it up, no matter the whos, whys, and hows. There was not one juncture of his life as I knew it that he had not tried to process through film. Film was his way to digest and release what he lived on, as essential to him as the functioning of his kidneys and liver. If the film did not turn out to be pleasing, well, that was the risk, so be it.

At the same time it dawned on me ("Like the jitterbug," said Lenny Bruce, "so simple it nearly eluded me") that Nick dreaded making films. To make a film as he wanted, "as a living, continuously breathing thing," was for him, perhaps, an act of creation too close to God's. In this cruel confusion Nick's gifts and successes turned into agents of torment and guilt. I believe, although he never said so, at heart Nick agreed with Welles: "Maybe there's some rightness in the difficulty."

True to his premonition Nick did not live to finish the film.

The courses in acting and directing for film that Nick taught in his last years were in all ways the culmination of his life work. He knew it and had the good sense to record the class sessions and to want their content made known. I knew I would do what he asked, although back then this assignment like that of the "autobiography" seemed more chore than opportunity.

I began work shortly after Nick's death for a bad mix of motives, none of them clear, and quit work dejected just weeks after that. Of course I had not grieved my loss yet, nor had I fought free from Nick's too big although friendly ghost-not to mention my own-to a ground on which I could stand firm alone. These were personal tasks 
both scary and inconvenient and they would not settle for less than my full attention. At the time I did not understand that grieving and fighting, fighting and grieving, were the stuff of what Nick called "the search for self," the stuff of his life and his movies and classes; so the grieving and fighting I saw before me I fiercely resented as a far too long nasty detour. But I followed my nose, or it dragged me along, until I learned at least two or three times that when it comes to how a life weaves itself there are no extra threads or loose ends-so detours need not be a problem. Of course it only made sense: I could not piece together Nick's search until I had started off on my own-but this I can say only now that the piecing is done. Anyway, it came to pass that I knew without doubt it was time to get back to work on Nick's teaching book or life story, whichever.

As I transcribed some one hundred-plus hours of often unlabeled and poorly recorded tapes and tried to read what he had written by hand in letters and notebooks, on cards and cocktail napkins, I had to mutter at Nick's carelessness with his records, at his obscurations and incompletions. "Never leave a trail of words," he had warned me the writer-to-be, while he himself left many trails all ending abruptly in one wilderness or another. The problem remained: How could so many fragments form a sensible whole? In his words: "But what shall I do about all the transitional phrases or pages necessary to make what follows comprehensible to you?"

I had seen Nick solve such a problem before and always the solution homed in how he felt for the integrity of his subject, for the subject is intrinsically whole without extra threads or loose ends-the same theme again. The burden falls on the observer to catch the pattern of the weave. So I gathered all the pieces I knew of Nick's life together and once more posed my old questions: Was Nick a master? What was a master? How could Nick's life be told to satisfy both him and me? What was Nick teaching? What was Nick really teaching?

History and facts still did not impel me, not on their own, but true emotion did impel, nurture, and free me as did the landscape in which it arose and dissolved and the wisdom it could leave behind. Finally I knew that much of myself and I knew it in a new way about Nick. Tracing what moved me about him I trusted the shape of his life to emerge of itself, a phoenix from the fragments, for I had been well taught: content determines form; form conditions the content.

The class transcripts form the skeleton of this book. They have been pieced into a composite combining three series of classes and three groups of students into one series, one group. The emphasis of each class session falls on the exploration of terms and/or techniques (ac- 
tion, monologue, backstory, sense memory, making an entrance). The sessions are linked by developing themes (the character party, "The Forger" scenario) and the evolution of the students' understanding.

But what Nick taught was not so much terms and techniques: Nick taught experience. He taught from experience, through experience, about the nature of experience, about analysing, integrating, and synthesizing experience into a gift of experience for others. Because this is so the class transcripts do not make a whole teaching text without reference to the experience-Nick's-from which their lessons are drawn. The work in class on "stripping ... down to the essential" and on the scenario of "The Forger," a man who "must steal another's identity," is the same work Nick did at home as he wrote about drink, love, and dying. The work at home fed the work in class and viceversa. To extract one from the other would be a theft of dimension and so perspective as dire as believing our world is flat.

Nick taught as he lived: he dove into chaos and found his way out and expected his students would do same. A good many did and have become respected directors, producers, editors, writers, and actors in theatre and film. For an impatient man Nick became a most patient teacher. What he taught was simple but not easy and he knew to repeat it in different contexts with different shadings until it was fully absorbed. He asked more questions than he gave answers for, as he said, he taught to learn and to awaken his students' intrinsic knowing, not bludgeon them with his own.

And what about my old questions? Almost two decades have passed since I first asked them. Since then I've met many people who spent time with Nick, if only an hour or two, and it's curious to me how many claim that he changed the course of their lives. I do not believe that was his intention, it just happened that way as he went about his own business. But then his business was acting. Whether before or behind or away from the camera Nick was an actor, one who "in ... three hours travels the whole course of the dead-end path that the man in the audience takes a lifetime to cover." 15 As an actor he could not help but take whomever was with him to the edge where he lived and then push-and surprise, they did not fall off and the world was not flat and who could forget the view. Nick acted all the time. Nick taught all the time. He taught through his actions, whether

15. Albert Camus. The Myth of Sisyphus and Other Essays (Random House, Inc., Vintage International, 1991). 
he meant to or not, whether his actions looked smart or insane. A hasidic tale tells of the student who goes to the master not to learn scripture but to watch how he ties his shoelaces. In that light maybe Nick was a master, for he did things so boldly and with such heart it was impossible not to watch him. It was impossible not to watch him because what he did was new and because as I watched I felt my own being grow brighter - not by reflection but by generation of light.

Really I'm not in a position to judge if Nick was a master or not, the question is not so interesting now. I know surely he was a seeker. He knew what questions to ask, he knew what it was he was after, whatever its name, however far he was from it. And I know I will not need more than the toes on one foot to count the true seekers I'm likely to meet in this lifetime. That I knew even one is a rare unaccountable boon.

However this book is read I offer it first as the telling of a journey. Not everyone makes movies or works in the theatre but everyone takes a journey, and it seems that no matter the style of the journey the landmarks are the same. That being the case, even the roughest map may prove a good guide and comfort. 